UDC 378.14:316.7 (045)

DOI: $10.31470 / 2415-3729-2018-8-167-181$

\title{
Normative-Legal Aspects of Training the Future Officers of the Ukrainian Merchant Navy to Work in Extreme Situations
}

\section{Dmytro Osadchuk}

postgraduate student of Khmelnytskyi National University

$\triangle 11$, Instytutska Str., Khmelnytskyi, Ukraine, 29016

E-mail: odd1968@ukr.net

ORCID: 0000-0002-0954-4130

Date of receipt of the article: August 03, 2018

Article accepted for publication: November 25, 2018

\section{Нормативно-правові аспекти підготовки майбутніх офіцерів морського торговельного флоту України до роботи в екстремальних ситуаціях}

\section{Дмитро Дмитрович Осадчук}

аспірант Хмельницького національного університету

$\triangle$ вул. Інститутська, 11, м. Хмельницький, Україна, 29016

Дата надходження статті: 03 серпня 2018 p. Стаття прийнята до друку: 25 листопада 2018 р.

\begin{abstract}
Training the future officers of the Ukrainian Merchant Navy to work in extreme situations is an important scientific problem at the present stage of the higher education system development and the maritime sector activity in Ukraine. Today Ukraine needs highly skilled Merchant Navy officers who will be competent in a variety of professional situations. The consideration of the norms and requirements of domestic and international legislation in the maritime sector is a prerequisite for the preparation of the competitive, skilled
\end{abstract}


specialist. The purpose of the article is the identification and analysis of domestic and international normative-legal documents concerning training of the future officers of the Ukrainian Merchant Navy to work in extreme situations. To conduct scientific research, such separate methods have been used as analysis, synthesis, generalization, systematization of scientific sources and regulatory documents for the identification and disclosure of key aspects of domestic and international legislation in the maritime sector in relation to training of the future officers of the Ukrainian Merchant Navy to work in extreme situations. Conclusions. The analysis of normative-legal aspects of training the future officers of the Ukrainian Merchant Navy to work in extreme situations gives fairly clear requirements for the qualification of such specialists. The compliance with international documents in the field of training marine specialists, due consideration in domestic legislation and in the work of maritime institutions of higher education will make it possible to prepare high-quality personnel in the field of merchant navy which will not only provide the industry with skilled personnel, but will also allow to raise qualitatively the level of private security of a key personnel and a crew, and the vessels' survivability.

Key words: future officers, Merchant Navy, extreme situations, normative-legal aspects, legislation.

\section{References}

1. Butsenko, S. V. (2006). Orhanizatsiino-pravovi zasady ukomplektuvannia kerivnoho skladu sudnovykh ekipazhiv v Ukraini[Organizational and legal principles of staffing the vessels key personnel in Ukraine]. Extended abstract of candidates thesis. Odessa: Odessa I. I. Mechnikov National University [in Ukraine].

2. Hlikman, S. V. (2017). Metodolohichne pidgruntia formuvannia profesiinykh yakostei maibutnikh sudnovodiiv [Methodological basis for the formation of future navigators professional qualities]. Zbirnyk naukovykh prats Natsionalnoi akademii Derzhavnoi prykordonnoi sluzhby Ukrainy. Seriia: Pedahohichni nauky - Collection of scientific works of the National Academy of the State Border Guard Service of Ukraine. Series: pedagogical sciences. 2 (9), 105-117 [in Ukraine].

3. Dudova, D. O. (2017). Pedahohichni umovy natsionalnopatriotychnoho vykhovannia maibutnikh fakhivtsiv morskoi haluzi 
$\mathrm{v}$ osvitnomu seredovyshchi koledzhu [Pedagogical conditions of the future maritime sector specialists national-patriotic upbringing in the educational environment of a college]. Visnyk Cherkaskoho universytetu. Seriia: Pedahohichni nauky - Cherkasy University Bulletin: Pedagogical Sciences, 6, 62-67 [in Ukraine].

4. Zakon Ukrainy «Pro vyshchu osvitu». (2014). [Law of Ukraine «On Higher Education»]. Retrieved from https://zakon.rada. gov.ua/laws/show/1556-18 [in Ukraine].

5. Kozak, S. V. (2001). Formuvannia inomovnoi komunikatyvnoi kompetentsii maibutnikh fakhivtsiv morskoho flotu [The formation of foreign language communicative competence of future specialists of the Navy] Extended abstract of candidates thesis. Odessa: South Ukrainian national pedagogical university named after K. D. Ushynsky [in Ukraine].

6. Kolegaev, M. A., Ivanov, B. N. \& Basanets, N. G. (2008). Bezopasnost zhiznedeyatelnosti i vyizhivanie na more [Life safety and survival at sea]. Odessa [in Russian].

7. Mizhnarodna konventsiia $\mathrm{z}$ okhorony liudskoho zhyttia na mori (1974). [International Convention for the Safety of Life at Sea]. Retrieved from https://zakon.rada.gov.ua/laws/show/995_251 [in Ukraine].

8. Mizhnarodna konventsiia pro pidhotovku i dyplomuvannia moriakiv ta nesennia vakhty (1978). [International Convention on Standards of Training, Certification and Watchkeeping for Seafarers, 1978]. Retrieved from https://zakon.rada.gov.ua/laws/show/995_053 [in Ukraine].

9. Mizhnarodnyi kodeks $\mathrm{z}$ okhorony suden ta portovykh zasobiv. (2002). [The International Ship and Port Facility Security Code]. Retrieved from https://zakon.rada.gov.ua/laws/show/896_035 [in Ukraine].

10. Mizhnarodnyi kodeks $\mathrm{z}$ upravlinnia bezpekoiu (MKUB) (1993). [International Security Management Code]. Retrieved from https://zakon.rada.gov.ua/laws/show/995_304 [in Ukraine].

11. Nakaz Ministerstva transportu Ukrainy «Pro zatverdzhennia Polozhennia pro systemu upravlinnia bezpekoiu sudnoplavstva na morskomu i richkovomu transporti» (2003). [Order of the Ministry of Transport of Ukraine «On Approval of the Regulation on the System 
of Safety Management of Navigation on Sea and River Transport»]. Retrieved from https://zakon.rada.gov.ua/laws/show/z1193-03/ ed20111209/find/sp:max 15 ?text=\%CC\%B3\%E6\%ED $\%$ E0\%F0\%EE\%E 4\%ED $\%$ E8\%E9+\%EA $\%$ EE $\%$ E4\%E5\%EA $\% \mathrm{~F} 1+\% \mathrm{E} 7+\% \mathrm{~F} 3 \% \mathrm{EF} \% \mathrm{~F} 0 \%$ $\mathrm{E} 0 \% \mathrm{E} 2 \% \mathrm{~EB} \% \mathrm{~B} 3 \% \mathrm{ED} \% \mathrm{ED} \% \mathrm{FF}+\% \mathrm{E} 1 \% \mathrm{E} 5 \% \mathrm{E} 7 \% \mathrm{EF} \% \mathrm{E} 5 \% \mathrm{EA} \% \mathrm{EE} \%$ $\mathrm{FE}+\% 28 \% \mathrm{CC} \% \mathrm{CA} \% \mathrm{D} 3 \% \mathrm{C} 1 \% 29$ [in Ukraine].

12. Postanova Kabinetu Ministriv Ukrainy «Pro zatverdzhennia Morskoi doktryny Ukrainy na period do 2035 roku» (2009). [Resolution of the Cabinet of Ministers of Ukraine «On Approval of the Marine Doctrine of Ukraine for the Period until 2035»]. Retrieved from https://zakon.rada.gov.ua/laws/show/1307-2009-\%D0\%BF [in Ukraine].

13. Rozlutskyi, O. M. (2015). Vyzhyvannia v ekstremalnykh umovakh [Survival in extreme conditions: program of study discipline]. Odesa: ONMA [in Ukraine].

14. Svarychevska, A. P. (2017). Metodychni rekomendatsii dlia vykladachiv shchodo vykorystannia zasobiv interaktyvnykh tekhnolohii $\mathrm{V}$ protsesi formuvannia ekolohichnoi kompetentnosti maibutnikh ofitseriv tsyvilnoho flotu: metod. rekom. dlia vykl. [Methodical recommendations for teachers on the use of interactive technologies in the process of forming the ecological competence of future civilian fleet officers]. Odessa [in Ukraine].

15. Slepchenko, O. O. (2014). Osoblyvosti administratyvnopravovykh norm, yaki vyznachaiut diialnist vyshchykh navchalnykh zakladiv iz pidhotovky fakhivtsiv dlia torhovoho flotu Ukrainy [Special administrative and legal norms which establish the higher education establishments activity on training specialists for the Merchant Navy of Ukraine]. Naukovyi visnyk Mizhnarodnoho humanitarnoho universytetu Seriia: Yurysprudentsiia - Scientific Herald of the International Humanitarian University. Series «Jurisprudence», 10-1, 1, 155-157 [in Ukraine].

16. Smirnov, S. V. (2017). Model formuvannia konkurentozdatnosti maibutnikh sudnovodiiv u protsesi profesiinoi pidhotovky [Model of forming the future ship navigators competitiveness in the process of professional training]. Naukovyi visnyk Mykolaivskoho natsionalnoho universytetu imeni V. O. Sukhomlynskoho - Scientific Herald Mykolaiv 
V. O. Sukhomlynskyi National University, 3 (58). S. 350-353 [in Ukraine].

\section{Вступ}

Розбудова української держави як важливого гравця на світовому ринку праці вимагає наявність конкурентоздатної системи освіти, яка здатна підготувати фахівців, котрі будуть конкурентоспроможними на вітчизняному та світовому ринках праці. Зокрема це стосується підготовки фахівців морської галузі, оскільки сьогодні Україна заявляє про себе як важливого гравця на світовому ринку морських перевезень. А тому нині зусилля науковців, науково-педагогічних працівників морських закладів вищої освіти, законодавців, чиновників у сфері транспорту спрямовані на вдосконалення змісту, пошук оптимальних та найбільш ефективних форм, методів та засобів підготовки фахівців морської галузі, що дасть змогу сформувати фахівця, який володіє належним рівнем професійної компетентності. Зокрема, це стосується підготовки майбутніх офіцерів морського торговельного флоту України до роботи в екстремальних ситуаціях.

Будь-яка діяльність у сфері підготовки майбутніх фахівців морського торговельного флоту України потребує нормативноправового регулювання, зокрема окремих іiї аспектів - підготовки до роботи в екстремальних ситуаціях. Нормативно-правове забезпечення та його дотримання в процесі професійної підготовки в морських закладах вищої освіти сприятиме дієвому засвоєнню знань, умінь i навичок, формуванню особистісних якостей, ключових компетентностей для успішної професійної діяльності в майбутньому. Тому на сьогодні важливо виробити чітку нормативно-правову базу для забезпечення якісної професійної підготовки майбутніх офіцерів морського торговельного флоту України до роботи в екстремальних ситуаціях. Їхня професійна підготовка сьогодні потребує чіткої регламентації та стандартизації. Зокрема, аналіз чинних нормативно-правових документів дає змогу визначити та розкрити провідні напрями удосконалення підготовки фахівців досліджуваного профілю.

Аналіз праць науковців 3 досліджуваної проблеми засвідчив, що сьогодні питання професійної підготовки майбутніх фахівців 
у морських закладах вищої освіти досліджується низкою вчених у різних напрямах, як-от: С. Буценко - організаційно-правові аспекти укомплектування керівного складу суднових екіпажів в Україні (Буценко, 2006), С. Глікман - формування професійних якостей майбутніх судноводіїв у процесі фахової підготовки (Глікман, 2017), Д. Дудова - національно-патріотичне виховання майбутніх фахівців морської галузі в освітньому середовищі коледжу (Дудова, 2017), С. Козак - формування іншомовної комунікативної компетентності майбутніх фахівців морського флоту (Козак, 2001), М. Колєгаєв, Б. Іванов, М. Басанець безпека життєдіяльності та виживання на морі (Колегаев, Иванов \& Басанец, 2008), А. Сваричевська - формування екологічної компетентності майбутніх офіцерів цивільного флоту (Сваричевська, 2017)], С. Слепченко - адміністративноправові норми підготовки фахівців для торговельного флоту України в закладах вищої освіти (Слепченко, 2014), С. Смірнов формування конкурентоздатності майбутніх судноводіїв у процесі професійної підготовки у морських закладах вищої освіти (Смірнов, 2017) та ін.

Однак дослідження нормативно-правових аспектів підготовки майбутніх офіцерів морського торговельного флоту України до роботи в екстремальних ситуаціях на сьогодні відсутнє, що і спричинило актуальність наших наукових пошуків. Водночас, досліджувана проблема $є$ надзвичайно важливою і 3 огляду формування професійних компетентностей у майбутніх фахівців морської галузі.

Метою статті $\epsilon$ виявлення та аналіз вітчизняних $i$ міжнародних нормативно-правових документів, які стосуються професійної підготовки майбутніх офіцерів морського торговельного флоту України до роботи в екстремальних ситуаціях.

\section{Матеріал і методи дослідження}

Для проведення дослідження було використано низку методів наукового пошуку, зокрема - аналіз, синтез, узагальнення та систематизація наукової літератури.

\section{Результати та їх обговорення}

Питання підготовки майбутніх офіцерів морського торговельного флоту України до роботи в екстремальних 
ситуаціях на сьогодні є одним із найбільш важливих. Ці питання порушуються під час опанування курсантами в морських закладах вищої освіти низки профільних навчальних дисциплін, однією 3 яких $\epsilon$ «Виживання в екстремальних умовах», оскільки виживання в екстремальних ситуаціях - це галузь наукового знання та практичної професійної діяльності, яка спрямовується на формування безпеки людини, яка знаходиться на морі, попередження виявам різних видів небезпек шляхом вивчення загальних закономірностей появи та вияву небезпек, їхніх властивостей, наслідків впливу на організм людини, основ захисту людини, ї життя, а також на розробку й реалізацію діяльності людини в екстремальних ситуаціях. Ця дисципліна спрямована на підготовку плавскладу суден до дій в різних екстремальних ситуаціях, які можуть мати місце в процесі їхньої професійної діяльності. Головною метою вивчення дисципліни є формування у людини свідомого й відповідального ставлення до питань особистої безпеки, а також безпеки оточуючих. Також важливим завданням $€$ навчання майбутніх фахівців морської галузі розпізнавати види наявних та потенційних небезпек, оцінювати їх ступінь, а також вміти спроектувати шляхи захисту від небезпек, що виникли, зокрема i формування вмінь надавати першу медичну допомогу (i coбi, i іншим), та швидко ліквідовувати наслідки вияву небезпек, які можуть статися під час професійної діяльності на морському транспорті (Розлуцький, 2015).

На думку М. Колєгаєва, Б. Іванова, М. Басанця, «одним i3 найбільш важливих факторів безпеки мореплавання - це компетентність судових екіпажів, тому підготовці моряків міжнародні організації приділяють особливу увагу. 3 цією метою IMO розроблено обов'язкові мінімальні вимоги (стандарти) щодо підготовки i дипломування моряків і несення вахти» (Колегаев, Иванов \& Басанец, 2008 с. 52).

У цьому контексті, Закон України «Про вищу освіту» наголошує на тому, що якість вищої освіти, здобутої особою, визначається наявним у неї рівнем знань, умінь, навичок, компетентностей, що відображає іiі компетентність відповідно до стандартів вищої освіти («Про вищу освіту», 2014).

Важливим для нашої наукової розвідки $є$ дослідження О. Слепченко щодо адміністративно-правових норм, які 
регламентують діяльність морських закладів вищої освіти у контексті підготовки фахівців для торговельного флоту. Погоджуємось із науковцем, що на сьогодні морські заклади вищої освіти $є$ учасниками адміністративно-правових відносин у сфері підготовки фахівців для морського торговельного флоту. За твердженням О. Слепченко, «вищим навчальним закладам із підготовки кадрів для торговельного форту в Україні притаманні такі ж ознаки, як і суб'єктам адміністративного права, оскільки: готують фахівців для торговельного флоту як із числа громадян України, так і іноземців; основним призначенням $\epsilon$ надання освітніх послуг; можуть знаходитись як у прямому підпорядкуванні Міністерству освіти i науки України, так i Міністерству аграрної політики та продовольства України; виступають як суб'єкти державного управління відносно курсантів та студентів та підпорядкованим їм структурних органів» (Слепченко, 2014, с. 155).

Акцентуючи увагу на нормативно-правовому аспекті досліджуваної проблеми, варто зазначити, що основними документами $\epsilon$ : Міжнародна конвенція про підготовку i дипломування моряків та несення вахти 1978 року (ПДНВ 78/95) 3 Манільськими поправками від 2010 р., Міжнародний кодекс з охорони суден і портових засобів (2002р.), Міжнародна конвенція 3 охорони людського життя на морі (СОЛАС-74) (1974 р.), Конвенція про Міжнародні правила попередження зіткнення суден на морі (МПСС-72) (1972 р.), Наказ Міністерства транспорту України «Про затвердження Положення про систему управління безпекою судноплавства на морському i річковому транспорті» (2003р.), Міжнародний кодекс з управління безпекою (МКУБ) (1993р.), Постанова Кабінету Міністрів України «Про затвердження Морської доктрини України на період до 2035 року» (2009 р.) та ін.

Розглянемо окремі аспекти цих нормативно-правових документів.

У Міжнародній конвенції про підготовку і дипломування моряків та несення вахти 1978 року (ПДНВ 78/95) зазначено, що метою укладення цієї Конвенції є установлення міжнародних норм, які стосуються підготовки та дипломування моряків і несення 
вахти, завдяки яким буде забезпечено охорона людського життя на морі та збереження майна. Відповідно сторони, які эii підписали, зобов’язані ухвалювати нормативно-правові акти (закони, накази, правила тощо), а також повинні вживати заходи, які сприятимуть збереженню людського життя на майна на морі, i які зможуть повноцінно забезпечити реалізацію ключових положень цієї Конвенції, у тому числі i які стосуються підготовки моряків із належним рівнем професійної кваліфікації та здатність якісно виконувати свої професійні обов'язки (Міжнародна конвенція про підготовку i дипломування моряків..., 1978). Зокрема у цьому документі також визначено мінімальні вимоги до дипломування спеціалістів командного складу, зокрема і щодо формування у них знань та навичок дій в екстремальних ситуаціях.

У Міжнародній конвенції 3 охорони людського життя на морі 1974 року чітко розписано їі визначення, які застосовуються,

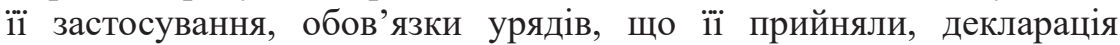
про охорону, обов'язки компанії, охорона судна, оцінка охорони судна, план охорони судна, записи, посадові особи компанії, які відповідають за охорону судна, особа командного складу судна, яка відповідає за його охорону, підготовка та навчання 3 питань охорони судна тощо. У цій конвенції $є$ низка правил, зокрема щодо правил плавання i маневрування, спостереження, безпечної швидкості, небезпеки зіткнення, дії для попередження зіткнення, плавання у вузькостях, плавання по системах розподілу руху, обгону (Міжнародна конвенція з охорони людського життя на морі, 1974).

У Міжнародному кодексі 3 охорони суден та портових засобів серед іншого йде мова про посадових осіб компанії, які відповідають за охорону, і про те, що вони повинні мати знання та отримати підготовку 3 урахуванням рекомендацій, наведених у частині В цього кодексу (Міжнародний кодекс 3 охорони суден..., 2002).

Відповідно до наказу Міністерства транспорту України «Про затвердження Положення про систему управління безпекою судноплавства на морському i річковому транспорті» (2003р.) визначено деякі аспекти забезпечення безпеки судноплавства в частині того, яким чином здійснювати роботи із попередження 
аварій на морському транспорті, визначено систему управління безпекою на морському транспорті (в частині завдань, функцій, а також суб'єктів та об'єктів цієї системи), встановлено форми контролю проведених заходів, які стосується безпеки судноплавства («Про затвердження Положення про систему управління безпекою судноплавства...» 2003).

Метою Міжнародного кодексу 3 управління безпекою (МКУБ) (1993р.) є забезпечення міжнародного стандарту 3 управління безпечною експлуатацією суден та попередження забруднень. Відповідно до нього, Компанія має забезпечити, щоб капітан: мав належну кваліфікацію для управління судном; був повністю ознайомлений про СУБ компанії; отримував необхідну підтримку для безпечного виконання своїх обов'язків (Міжнародний кодекс з управління безпекою, 1993).

Постанова Кабінету Міністрів України «Про затвердження Морської доктрини України на період до 2035 року» (2009р.) наголошує на тому, що до сьогодні одним із важливих завдань $\epsilon$ повноцінне використання морських ресурсів для розвитку українського суспільства в цілому, та економіки зокрема. Для покращення позицій України на світовому морському торговельному мореплавстві, важливим $\epsilon$ забезпечення його безпеки, шляхом, серед інших, провадження морегосподарської діяльності, яка стосується підготовки та перепідготовки моряків, науковців та інших фахівців, які мають відношення до організації та здійснення робіт на морі. Напрямами відродження і розвитку торговельного мореплавства, з-поміж інших, є: підготовка, перепідготовка і дипломування моряків, інших фахівців морського транспорту, розроблення та виконання комплексного плану оновлення кадрового потенціалу морського транспорту відповідно до інноваційної моделі розвитку морської індустрії, відновлення системи післядипломної підготовки фахівців, забезпечення високих соціальних стандартів для моряків («Про затвердження Морської доктрини України на період до 2035 року», 2009).

Таким чином, міжнародне i вітчизняне законодавство в морській галузі вимагає, щоб рівень знань, практичних умінь i навичок випускників морських закладів вищої освіти був достатнім для забезпечення виживання на морі, надання першої 
медичної допомоги, протипожежної безпеки й боротьби 3 пожежею на судні, особистої безпеки й суспільних відносин. Кожен здобувач вищої освіти зобов'язаний продемонструвати належний рівень компетентності, який відповідатиме методам та критеріям оцінки такої компетентності. А це можливо лише за умов урахування в професійній підготовці вимог міжнародних i вітчизняних нормативно-правових актів, які впливають на підготовку таких фахівців, а також від того, на скільки курсанти майбутні офіцери морського торговельного флоту - самі знатимуть та дотримуватимуться вимог цих документів.

\section{Висновки}

Отже, проведений аналіз нормативно-правових аспектів підготовки майбутніх офіцерів морського торговельного флоту України до роботи в екстремальних ситуаціях дає досить чіткі вимоги до кваліфікації таких фахівців. Дотримання міжнародних документів у сфері підготовки фахівців морського профілю, належне його врахування у вітчизняному законодавстві та в діяльності морських закладів вищої освіти дасть змогу підготувати якісні кадри у сфері морського торговельного флоту, що не лише забезпечить галузь кваліфікованими кадрами, а й дасть змогу якісно підвищити рівень особистої безпеки керівного складу та складу команди, а також живучості суден.

Перспективними напрямами подальших досліджень вважаємо розробку рекомендацій щодо удосконалення професійної підготовки майбутніх офіцерів морського торговельного флоту України до роботи в екстремальних ситуаціях, на основі вимог ключових нормативно-правових документів (вітчизняних i міжнародних), а також підвищення якості практичного складника підготовки таких фахівців.

\section{Література}

1. Буценко С. В. Організаційно-правові засади укомплектування керівного складу суднових екіпажів в Україні: автореф. дис. канд. юрид. наук: 12.00.07 / Одеський національний ун-т ім. І. І. Мечникова. Одеса, 2006. 20 с.

2. Глікман С. В. Методологічне підгрунтя формування професійних якостей майбутніх судноводіїв. Збірник наукових 
працьь Національної академії Державної прикордонної служби Украӥни. Сер.: Педагогічні науки. Хмельницький: НАДПСУ, 2017. № 2 (9). С. 105-117.

3. Дудова Д. О. Педагогічні умови національнопатріотичного виховання майбутніх фахівців морської галузі в освітньому середовищі коледжу. Вісник Черкаського університету. Сер.: Педагогічні науки. Черкаси, 2017. № 6. 2017. С. 62-67.

4. Закон України «Про вищу освіту». URL: https://zakon. rada.gov.ua/laws/show/1556-18 (Дата звернення 15.06.2018).

5. Козак С. В. Формування іномовної комунікативної компетенції майбутніх фахівців морського флоту: автореф. дис. канд. пед. наук: 13.00 .04 / Південноукр. держ. пед. ун-т ім. К. Д. Ушинського. Одеса, 2001. 20 с.

6. Колегаев М. А., Иванов Б. Н., Басанец Н. Г. Безопасность жизнедеятельности и выживание на море: учеб пособ. [2-е изд.]. Одесса, 2008. 352 с.

7. Міжнародна конвенція 3 охорони людського життя на морі 1974 p. (СОЛАС-74). URL: https://zakon.rada.gov.ua/laws/ show/995_251 (Дата звернення 10.06.2018).

8. Міжнародна конвенція про підготовку і дипломування моряків та несення вахти 1978 року (ПДНВ 78/95. URL: https:// zakon.rada.gov.ua/laws/show/995_053 (Дата звернення 10.06.2018).

9. Міжнародний кодекс 3 охорони суден та портових засобів. URL: https://zakon.rada.gov.ua/laws/show/896_035 (Дата звернення 10.06.2018).

10. Міжнародний кодекс з управління безпекою (МКУБ) (1993 р.) URL: https://zakon.rada.gov.ua/laws/show/995_304 (Дата звернення 12.06.2018).

11. Наказ Міністерства транспорту України «Про затвердження Положення про систему управління безпекою судноплавства на морському і річковому транспорті» (2003р.). URL: https://zakon.rada.gov.ua/laws/show/z1193-03/ed20111209/find/ sp:max 15 text $=\% \mathrm{CC} \% \mathrm{~B} 3 \% \mathrm{E} 6 \% \mathrm{ED} \% \mathrm{E} 0 \% \mathrm{~F} 0 \% \mathrm{EE} \% \mathrm{E} 4 \% \mathrm{ED} \% \mathrm{E} 8 \% \mathrm{E} 9$ $+\% \mathrm{EA} \% \mathrm{EE} \% \mathrm{E} 4 \% \mathrm{E} 5 \% \mathrm{EA} \% \mathrm{~F} 1+\% \mathrm{E} 7+\% \mathrm{~F} 3 \% \mathrm{EF} \% \mathrm{~F} 0 \% \mathrm{E} 0 \% \mathrm{E} 2 \% \mathrm{~EB} \% \mathrm{~B}$ $3 \% \mathrm{ED} \% \mathrm{ED} \% \mathrm{FF}+\% \mathrm{E} 1 \% \mathrm{E} 5 \% \mathrm{E} 7 \% \mathrm{EF} \% \mathrm{E} 5 \% \mathrm{EA} \% \mathrm{EE} \% \mathrm{FE}+\% 28 \% \mathrm{CC} \%$ $\mathrm{CA} \% \mathrm{D} 3 \% \mathrm{C} 1 \% 29$ (Дата звернення 12.06.2018).
12. Постанова
Кабінету
Міністрів
України «Про затвердження Морської доктрини України на період до 
2035 року». URL: https://zakon.rada.gov.ua/laws/show/1307-2009\%D0\%BF (Дата звернення 12.06.2018).

13. Розлуцький О. М. Виживання в екстремальних умовах: програма навч. дисц. Одеса: ОНМА, 2015. 16 с.

14. Сваричевська А. П. Методичні рекомендації для викладачів щодо використання засобів інтерактивних технологій в процесі формування екологічної компетентності майбутніх офіцерів цивільного флоту: метод. реком. для викл. Одеса, 2017. $51 \mathrm{c}$.

15. Слепченко О. О. Особливості адміністративноправових норм, які визначають діяльність вищих навчальних закладів із підготовки фахівців для торгового флоту України. Науковий вісник Міжнародного гуманітарного університету. Сер.: Юриспруденція. 2014. № 10-1, т. 1. С. 155-157.

16. Смірнов С. В. Модель формування конкурентоздатності майбутніх судноводіїв у процесі професійної підготовки. Науковий вісник Миколаївського національного університету імені В. О. Сухомлинського: зб. наук. праць. Сер.: Педагогічні науки. Миколаїв, 2017. № 3 (58). С. 350-353.

Осадчук Д. Д.

Нормативно-правові аспекти підготовки майбутніх офіцерів морського торговельного флоту України до роботи в екстремальних ситуаціях

\section{Анотація}

Підготовка майбутніх офіцерів морського торговельного флоту України до роботи в екстремальних ситуаціях $\epsilon$ важливої наукової проблемою на сучасному етапі розвитку системи вищої освіти та діяльності морської галузі в Україні. Україна сьогодні потребує висококваліфікованих офіцерів морського торговельного флоту, які будуть компетентними в різних ситуаціях професійної діяльності. Врахування норм і вимог вітчизняного та міжнародного законодавства в морській галузі $є$ необхідною умовою підготовки конкурентоспроможного, кваліфікованого фахівця. Проведений 
аналіз нормативно-правових аспектів підготовки майбутніх офіцерів морського торговельного флоту України до роботи в екстремальних ситуаціях дає досить чіткі вимоги до кваліфікації таких фахівців. Дотримання міжнародних документів у сфері підготовки фахівців морського профілю, належне його врахування у вітчизняному законодавстві та у діяльності морських закладів вищої освіти дасть змогу підготувати якісні кадри у сфері морського торговельного флоту, що не лише забезпечить галузь кваліфікованими кадрами, а й дасть змогу якісно підвищити рівень особистої безпеки керівного складу та складу команди, а також живучості суден.

Ключові слова: майбутні офіцери, морський торговельний флот, екстремальні ситуації, нормативно-правові аспекти, законодавство.

Осадчук Д. Д.

Нормативно-правовые аспекты подготовки будущих офицеров морского торгового флота Украины к работе в экстремальных ситуация

\section{Аннотация}

Подготовка будущих офицеров морского торгового флота Украины к работе в экстремальных ситуациях является важной научной проблемой на современном этапе развития системы высшего образования и деятельности морской отрасли в Украине. Украина сегодня нуждается в высококвалифицированных офицерах морского торгового флота, будут компетентными в различных ситуациях профессиональной деятельности. Учет норм и требований отечественного и международного законодательства в морской отрасли является необходимым условием подготовки конкурентоспособного, квалифицированного специалиста. Проведенный анализ нормативно-правовых аспектов подготовки будущих офицеров морского торгового флота Украины к работе в экстремальных ситуациях дает достаточно четкие требования к квалификации таких специалистов. Соблюдение международных 
документов в сфере подготовки специалистов морского профиля, должный его учет в отечественном законодательстве и в деятельности морских высших учебных заведений позволит подготовить качественные кадры в сфере морского торгового флота, не только обеспечит отрасль квалифицированными кадрами, но и позволит качественно повысить уровень личной безопасности руководящего состава и состава команды, а также живучести судов.

Ключевые слова: будущие офицеры, морской торговый флот, экстремальные ситуации, нормативно-правовые аспекты, законодательство. 